\title{
Characteristic of Screening for COVID-19 In Women Pregnant which Gestational Age>37 weeks Dr. Soetomo Hospital and Airlangga University Hospital November 2020
}

Letizia Alessandrinia ${ }^{a}$ M.Ardian Cahya Laksamana ${ }^{\text {b }}$

*Email: m.ardian@fk.unair.ac.id

${ }^{a}$ Obstetrics and Gynecology Resident of Airlangga University, dr. Soetomo Teaching Hospital, Surabaya 60115, Indonesia bobstetrics and Gynecology Department Staff of Airlangga University, dr. Soetomo Teaching Hospital, Surabaya 60115, Indonesia

\begin{abstract}
This study aims to find out the characteristic of screening COVID-19 in a pregnant woman who had a delivery at DR. Soetomo Hospital or Airlangga University Hospital. This is a descriptive study of 65 patients from Airlangga University Hospital and 32 patients from Dr. Soetomo Hospital in November 2020. This study shows that the age of patients who were pregnant during a pandemic was mostly in the age of 21-35 years old in both hospitals. The patients also showed they still routinely did the antenatal care ( $\pm>3$ times) even though the situation was still pandemic. Thus, The data shows that all pregnant women had good information about screening COVID-19 before delivery, and as a result, $\pm 77 \%$ of patients in Airlangga University Hospital received the screening COVID-19 in the form of swab PCR before delivery. This study also tried to find out the outcome of the patient's babies during pandemic COVID 19 in November 2020 which mostly has baby weight $>2500 \mathrm{~g}$, 91\% from Airlangga University Hospital and 88\% from Dr. Soetomo Hospital.
\end{abstract}

Keywords: screening COVID-19, pregnant women

\section{Introduction}

Coronavirus disease 2019 (COVID-19) is a respiratory infection caused by the coronavirus that first appeared in Wuhan, China, in December 2019. Coronavirus can cause severe symptoms which also can easily affect women in pregnancy. The transmission can be in various ways including contact transmission, droplet (splash), through the air (airborne), fomite, fecal-oral, through blood from mother to child, or from animals to humans (WHO, July 2020). SARS-CoV-2 infection generally causes mild to severe respiratory illness and death, while some people infected with this virus have not shown any symptoms. Currently, the spread of SARS-CoV-2 from human to human is the main source of transmission so that the spread becomes more aggressive (Han, 2020). Several case reports suggest that transmission from asymptomatic carriers is suspected, but the exact mechanism is unknown. Cases related to transmission from asymptomatic carriers generally have a history of close contact with COVID-19 patients (4).

\section{Methods}

This research is a descriptive study using medical record data at Dr. Soetomo Hospital and Airlangga University Hospital in November 2020. The population of this study was pregnant women with gestational age > 37 weeks who did the antenatal care and delivery at Dr. Soetomo Hospital or Airlangga University Hospital in November 2020. 


\section{Results}

Table 1. Characteristics of Pregnant Women in Airlangga University Hospital \& Dr. Soetomo Hospital

$\begin{array}{ll}\text { Airlangga } & \text { Dr.Soetomo } \\ \text { University } & \text { Hospital } \\ \text { Hospital } & \text { (32 patients) } \\ \text { (65 patients) } & \end{array}$

Age of patient

$-\quad \leq 20$ y.o

$11 \% \quad 0 \%$

- 21-35 у.о

$77 \% \quad 88 \%$

$-\quad \geq 35$ y.o

$11 \%$

$12 \%$

Parity

- Primi gravid $\quad 14 \% \quad 38 \%$

- Multi gravid $\quad 86 \% \quad 62 \%$

Antenatal care

$-\quad \leq 3$ times

$17 \%$

$46 \%$

$-\quad \geq 3$ times

$83 \%$

$54 \%$

Education about COVID 19 in

Public Health Care

- Yes

$97 \%$

$50 \%$

- No

$3 \%$

$50 \%$

Education about COVID 19 in hospital

$$
\text { - Yes }
$$$$
\text { - No }
$$

Screening COVID 19

Antigen

$$
\text { - Yes }
$$$$
\text { - No }
$$

Screening COVID 19

Swab PCR

$$
\text { - Yes }
$$$$
\text { - No }
$$

Screening COVID 19

Foto Thorax

$$
\text { - Yes }
$$$$
\text { - No }
$$

Mode of Delivery

- Spontaneous delivery

- Cesarean delivery

The outcome of the baby

Fetal body weight

$$
\text { - } \leq 2500 \mathrm{~g}
$$$$
-\quad \geq 2500 \mathrm{~g}
$$

$9 \%$

$91 \%$

$13 \%$

$88 \%$

The outcome of the baby

Asphyxia

$$
\text { - Yes }
$$$$
\text { - No }
$$

$100 \%$

$0 \%$

$100 \%$

$0 \%$

$62 \%$

$38 \%$

$20 \% \quad 38 \%$

$91 \% \quad 87 \%$

$9 \% \quad 13 \%$

$51 \% \quad 25 \%$

$49 \% \quad 75 \%$




\section{Discussion}

In this study, the sampling was carried out at Dr. Hospital. Soetomo Surabaya and Airlangga University Hospital. Dr. Soetomo Hospital is a type A hospital that is a referral center for eastern Indonesia. Meanwhile, Airlangga University Hospital is a type B teaching hospital located in the city of Surabaya. There were differences number of inpatient admissions through polyclinic and emergency departments Dr. Soetomo Hospital and Airlangga University Hospital in November 2020. It was found that in November 2020 the number of patients was 32 patients from Dr. Soetomo hospital and 65 patients from Airlangga University Hospital.

During November 2020 period, the highest age prevalence inpatients from the Maternity Clinic and Emergency Room at Dr. Soetomo Hospital and Airlangga University Hospital was at age 21-35 years, whereas the highest number of parity was multi gravid $\pm 75 \%$ at Dr. Soetomo Hospital and $\pm 86 \%$ from the Airlangga University Hospital.

The results of this study showed that the patients have routinely controlled more than 3 times at Dr. Soetomo Hospital $\pm 54 \%$ and Airlangga University Hospital $\pm 83 \%$ during a pandemic. This shows that the patients have an awareness about the importance of antenatal care in their pregnancy even though they were in a pandemic situation. The working group of Reproductive Tract Infections recommends that antenatal examinations during pregnancy be recommended at least 6 times face-to-face regardless of the status of the Covid-19 zone in the area, and telemedicine examinations can be added as needed ${ }^{(5)}$

This study found that $\pm 50 \%$ of patients had received education about COVID 19 before the patient was referred to Dr. Soetomo Hospital and $\pm 97 \%$ to Airlangga University Hospital. Moreover, the data shows that $100 \%$ of patients have received a re-explanation of COVID-19 before delivery.

Pregnant women who did the antenatal care at the Airlangga University Hospital have received a reexplanation about screening COVID $19 \pm 1$ week before the estimated due date of delivery. It is advisable to do a swab PCR examination before delivery at the nearest Public Health Center. The data found that $\pm 77 \%$ of patients had done a swab PCR at the Public Health Center in their respective areas. Although $\pm 23 \%$ of patients did not have swab PCR before delivery because they have not done a swab PCR examination or some patients are still waiting for the results of the swab PCR.

The rapid test examination was one of the tests that can be done for screening COVID 19 besides swab PCR. It was only be done when the patient was in charge in the hospital, if they has a swab PCR result in more than 7 days or if the patient is suspected of having symptoms at the time of in charge. The data shows that patients who routinely perform antenatal care at the Airlangga University Hospital had screened for COVID-19 in the form of a swab PCR examination to prepare for delivery. The results of these data are different from inpatients through the ER who have had a swab done during antenatal care examinations, only $34 \%$ of patients. Meanwhile, for the rapid test, the $\operatorname{IgG}(+)$ result was $21 \%$ and $\operatorname{IgG} / \operatorname{IgM}(+)$ was $10 \%$.

In patients who routinely antenatal care in polyclinic Dr. Soetomo Hospital showed that almost all patients $(100 \%)$ had a rapid test. The results of the data show that the rapid test results were $\pm 13 \%$ reactive and $88 \%$ nonreactive. For patients with positive rapid test results (13\%), patients were consulted to the polyclinic for COVID-19 to get the treatment until they are declared free from COVID-19. Moreover, the data found that $\pm 62 \%$ of patients had 
done the swab PCR before delivery and $\pm 13 \%$ patients from $\pm 62 \%$ had done the swab PCR from the referring public health center before they came to the polyclinic Dr. Soetomo Hospital. That's possibly due to the lack of information from the public health center during the antenatal care that they should conduct the swab PCR before they came to the hospital for delivery.

X-ray examination can be done as a first-line approach, although it is not as effective as a CT scan of the thorax ${ }^{(4)}$. Examination of the chest X-ray is an effort to maintain the security and safety for health workers and all patients when patients are hospitalized for delivery at Dr. Soetomo hospital, apart from a rapid test or swab PCR examination. The result of chest X-ray during hospitalized was $\pm 87 \%$ had done the X-ray examination which the result was within $\pm 75 \%$ within normal limit and $\pm 25 \%$ had pneumonia. Other data were obtained at the Airlangga University Hospital had $\pm 91 \%$ patients with a chest x-ray examination which the result was $\pm 86 \%$ within normal limits, $3 \%$ pneumonia, and other features were $2 \%$ (ex: cardiomegaly).

This study found that the prevalence of mode of delivery in a pregnant woman at Dr. Soetomo Hospital was $\pm 25 \%$ vaginal delivery and $\pm 75 \%$ abdominal delivery, while at Airalngga University Hospital had higher results in vaginal delivery $\pm 51 \%$ and $\pm 49 \%$ with abdominal delivery

The baby's birth weight who were born at Dr. Soetomo Hospital in November $2020>2500 \mathrm{~g}$ were $\pm 88 \%$ and $13 \%$ for 1000-2500g, meanwhile in Airlangga University Hospital had $\pm 91 \%$ baby birth weight was $>2500 \mathrm{~g}$ and $\pm 9 \%$ for $<2500 \mathrm{~g}$. Furthermore, $\pm 100 \%$ of the condition of the baby at birth in Dr. Soetomo Hospital and Airlangga University Hospital did not experience asphyxia.

\section{Conclusion}

The Indonesian government has several strategies to reduce the spread of COVID-19 in pregnant women. One of the efforts is to increase the information and education about COVID-19 screening which can be carried out by health care providers. Pregnant women can use the facilities that have been provided, including free swab PCR examination before delivery at their respective public health centers. The study found that pregnant women have received good information during antenatal care about COVID-19 screening. Thus, swab PCR examinations and rapid tests had been carried out on almost all pregnant women with gestational age $>37$ weeks at RSUD Dr. Soetomo and the Airlangga University Hospital in November 2020. It is hoped that communication, information, and education regarding COVID-19 screening services during antenatal care will continue to be improved the service of midwives, public health centers, and hospitals.

\section{Conflict of Interest}

The author declares that they have no conflict of interest.

\section{Source of Funding}

None.

\section{Ethical Approval}

This study was approved by the Health Research Ethics Committee of Airlangga University Hospital and Dr. Soetomo General Hospital, Surabaya, Indonesia (Approval number: 188/KEP/2020) 


\section{References}

1. World Health Organization diunduh dari https://www.who.int/docs/default- source/coronaviruse/situationreports/20200130-sitrep-10-ncov.pdf?sfvrsn=d0b2e480_2

2. Riedel S, Morse S, Mietzner T, Miller S. Jawetz, Melnick, \& Adelberg's Medical Microbiology. 28th ed. New York: McGraw-Hill Education/Medical; 2019. p.617-22.

3. Gorbalenya AE, Baker SC, Baric RS, de Groot RJ, Drosten C, Gulyaeva AA, et al. The species Severe acute respiratory syndrome-related coronavirus: classifying 2019-nCoV and naming it SARS-CoV-2. Nat Microbiol. 2020; published online March 2. DOI:10.1038/s41564-020-0695

4. Han Y, Yang H. The transmission and diagnosis of 2019 novel coronavirus infection disease (COVID19): A Chinese perspective. J Med Virol. 2020; published online March DOI: 10.1002/jmv.25749

5. Pokja Infeksi Saluran Reproduksi, Rekomendasi Penanganan Virus Corona (COVID-19) pada Maternal (Hamil,Bersalin dan Nifas). Skrining \& Diagnosis COVID-19 pada Maternal, hal 21, Jakarta, 2020. 